PRACE NAUKOWE UNIWERSYTETU EKONOMICZNEGO WE WROCLAWIU

\title{
Krzysztof Błoński
}

Uniwersytet Szczeciński

e-mail: kblonski@wneiz.pl

\section{JAKOŚĆ USŁUG ŚWIADCZONYCH \\ PRZEZ ADMINISTRACJĘ SAMORZĄDOWA A JAKOŚĆ ŻYCIA MIESZKAŃCÓW - WYNIKI BADAŃ \\ THE QUALITY OF SERVICES PROVIDED BY LOCAL ADMINISTRATION VS. THE QUALITY OF LIFE OF RESIDENTS - RESULTS OF RESEARCH}

DOI: $10.15611 /$ pn.2016.460.22

JEL Classification: I31

Streszczenie: Celem artykułu jest prezentacja wyników badań pierwotnych pozwalających na weryfikację relacji pomiędzy satysfakcją mieszkańców wybranych miast z usług świadczonych przez administrację samorządową a odczuwaną przez nich jakością życia. Artykuł ma charakter badawczy i przygotowano go na podstawie wyników badania ankietowego. W postępowaniu badawczym korzystano również z literatury dotyczącej jakości życia, jakości usług oraz satysfakcji klienta dostępnej w postaci książek i artykułów. Wyniki przeprowadzonej analizy skupień pozwalają na wyciągnięcie wniosku, iż wyższym ocenom zadowolenia $\mathrm{z}$ warunków życia w mieście towarzyszą wyższe oceny zadowolenia z całokształtu własnego życia oraz jakości usług dostarczanych przez władze miasta.

Słowa kluczowe: jakość życia, satysfakcja klienta, samorząd lokalny.

Summary: The purpose of this article is to present the results of primary research that allows to verify the relationship between the satisfaction of residents of selected cities with the services provided by the local administration and the quality of life they feel. The article is of investigative nature and it has been prepared on the basis of the survey results. In the research process also the literature on quality of life, quality of services and customer satisfaction, available in the form of books and articles, was used. The results of the carried out cluster analysis lead to the conclusion that higher assessments of satisfaction with living conditions in the city are accompanied by higher overall satisfaction ratings with one's own life and the quality of services provided by the city authorities.

Keywords: quality of life, customer satisfaction, local government. 


\section{Wstęp}

Początków zainteresowania pojęciem jakości życia można doszukiwać się w poglądach Hipokratesa (wyrazem szczęśliwego życia ma być stan wewnętrznej równowagi) czy Arystotelesa (najważniejszy cel to dążenie do eudajmonii). W czasach nowożytnych, na przełomie lat siedemdziesiątych i osiemdziesiątych XX wieku, jakość życia została włączona do obszaru badań socjologii, psychologii i medycyny. Współcześnie pojęcie jakości życia jest obecne również w zagadnieniach dotyczących filozofii czy ekonomii społecznej ${ }^{1}$. Za prekursora badań nad jakością życia uważa się Campbella, który wraz z Converesem i Rodgersem przeprowadził w 1971 r. badania, których celem był pomiar zadowolenia z własnego życia mieszkańców Stanów Zjednoczonych [Campbell 1976; Campbell, Converse, Rogers 1976]. Przedmiotem pomiaru był subiektywny poziom jakości życia zorganizowanej społeczności, aby ocenić zmiany dokonujące się w życiu ludzi. Jedna w pierwszych definicji jakości życia została sformułowana przez Dalkeya i Rourke’a i zakładała, że jej elementami są satysfakcja z życia i poczucie szczęścia [Dalkey, Rourke 1972].

Autor, mając świadomość braku w naukach społecznych przyjmowanej przez wszystkich uniwersalnej definicji jakości życia, zakłada na potrzeby niniejszej publikacji, że jakość życia to obraz życia człowieka oparty na określonym systemie wartości (systemie aksjologicznym). Ukształtowany obraz należy traktować jako zbiorowy atrybut człowieka lub grupy ludzi w zależności od użytych narzędzi jego opisu. Przedstawiony obraz może być wyrażany subiektywnie lub obiektywnie, jednowymiarowo lub wielowymiarowo [Borys 2008].

Jednym z czynników kształtujących jakość życia jest miejsce zamieszkania rozumiane jako jednostka osadnicza (miasto/wieś/obszar terytorialny) oferująca mieszkańcom określone korzyści. Wynikają one m.in. ze sposobu i stanu realizacji przypisanych danej jednostce osadniczej funkcji endogenicznych i egzogenicznych [Szymańska 2008]. Zgodnie bowiem z ustawą o samorządzie gminnym nadrzędnym celem jej władz miasta/gminy jest zaspokajanie potrzeb wspólnoty poprzez kreowanie określonych warunków jakości życia [Ustawa o samorządzie gminnym 2001]. Co odnosi się również do kwestii odpowiedniej jakości usług publicznych, której miarą jest satysfakcja klienta.

Satysfakcja klienta z usług świadczonych przez administrację samorządową w swojej istocie nie różni się od satysfakcji klienta z produktów lub usług organizacji nastawionych na zysk. Bazując na definicji R.B. Woodruffa i S.F. Gardiala ${ }^{2}$

\footnotetext{
${ }^{1}$ Odrębnym obszarem jest tzw. jakość życia w miejscu pracy. Traktowana jest ona jako narzędzie doskonalenia funkcjonowania organizacji. Kojarzona jest z takimi pojęciami, jak: etyka, produktywność, społeczna odpowiedzialność biznesu oraz wyniki funkcjonowania organizacji. Pojęcie pojawiło się w latach 60. ubiegłego wieku i jest obszarem zainteresowania dla osób zajmujących się problematyką zarządzania zasobami ludzkimi oraz reprezentantów behawioralnej szkoły zarządzania.

2 „Pozytywne lub negatywne odczucia klienta w związku z wartością, którą otrzymał jako rezultat skorzystania z określonej oferty produktowej w specyficznej sytuacji. Odczucie to może być wynikiem bezpośredniej reakcji na korzystanie z produktu lub całkowitą reakcją na serię doświadczonych sytuacji" [Woodruff, Gardial 1996, s. 95].
} 
[1996] można stwierdzić, że jest to emocjonalna reakcja klienta, odbiorcy w związku z wartością, jaką otrzymał w wyniku świadczenia usług przez urząd ST. Pojawić się ona może jako wynik jednorazowego korzystania z usług danego urzędu, jak również być reakcją na serię doświadczonych sytuacji. Czas trwania uczucia zadowolenia jest ograniczony, wraz z upływem czasu satysfakcja maleje i zanika. Wynika to z faktu, że powody i źródła satysfakcji powszednieją i są odbierane jako sytuacja przeciętna, przez co nie budzą już takich pozytywnych emocji.

Na satysfakcję klienta z usług JST można spojrzeć z jego punktu widzenia oraz punktu widzenia organizacji świadczącej usługi. Satysfakcja klienta z usług administracji samorządowej jest pojęciem subiektywnym, co wynika z faktu, że poszczególne osoby mogą daną sytuację różnie postrzegać i oceniać. Na poziom zadowolenia w zdecydowanym stopniu wpływają oczekiwania klientów, które z kolei mogą się kształtować pod wpływem wielu różnych czynników. Usługi świadczone przez administrację samorządową i towarzyszące jej ewentualne zadowolenie mogą być inaczej postrzegane z perspektywy klienta, a inaczej z perspektywy obywatela. Taka sytuacja wynika z pełnienia przez odbiorcę usług różnych ról, wynikających ze specyfiki sektora publicznego oraz ewolucji relacji urzędnik - klient.

Satysfakcja klienta z perspektywy organizacji sektora publicznego stanowi wartość samą w sobie i jeden z głównych celów działania [Demski 2003]. Z punktu zarządzania urzędem administracji samorządowej satysfakcja klienta jest nie tylko oceną jakości świadczonych usług [Modzelewski 2009], ale również wyznacznikiem realizowanej przez urzędy orientacji na klienta [Andreaseen 1994], jak również jednym z wskaźników sukcesu organizacji [Strąk 2012]. W ramach systemów zarządzania jakością satysfakcja klienta jest traktowana jako wyznacznik skuteczności działania urzędu [Bugdol 2011].

W literaturze przedmiotu można spotkać empiryczną weryfikację istnienia związku pomiędzy satysfakcją z życia zawodowego a jakością życia (np. A. Wołowska [2013] czy M. Kowalska i inni [2010]). Natomiast badania przeprowadzone przez T.S. Dagger, J.C. Sweeney [2006] wskazują, że jakość usług i odczuwalna przez klientów satysfakcja z nich wzmacniają jakość życia. W polskiej literaturze wyniki tych badań przytacza m.in. M. Bugdol [2011], który wskazuje na możliwość istnienia wpływu jakości świadczonych usług przez urzędy administracji publicznej na jakość życia. Przyjmuje on, że poziom usług bezpośrednio świadczonych przez urząd i odczuwany z nich poziom satysfakcji nie pozostaje bez wpływu na poziom oceny jakości życia, ale wskazuje na większy wpływ na odczuwaną jakość życia usług pośrednich. $\mathrm{O}$ wpływie jakości usług publicznych na jakość życia wspomina również R. Przygodzka [2010]. Wskazuje ona, że usługi publiczne są istotną częścią gospodarki poprzez zapewnienie miejsc pracy i wpływają na poziom dochodów w wielu sektorach (administracja, edukacja, ochrona zdrowia, usługi transportowe, komunalne itp.). Koszty świadczenia usług (np. komunalnych) kształtują zaś poziom kosztów utrzymania gospodarstw domowych. Usługi edukacyjne stwarzają nato- 
miast szanse na podniesienie jakości kapitału intelektualnego. Zapewnienie dostępu do usług w zakresie ochrony zdrowia pozwala poprawić kondycję zdrowotną społeczeństwa oraz zwiększyć oczekiwaną długość życia. Natomiast dostęp do usług dotyczących pomocy społecznej pozwala na wspieranie rodzin i osób niemogących poradzić sobie z różnych powodów i niebędących w stanie samodzielnie zapewnić sobie minimalnego standardu życia [Przygodzka 2010]. Związek jakości usług publicznych i jakości życia jest również uwzględniany w badaniach (np. Europejskie Badania Jakości Życia - EQLS).

Celem artykułu jest prezentacja wyników badań pierwotnych pozwalających na weryfikację zależności/relacji pomiędzy satysfakcją mieszkańców wybranych miast z usług świadczonych przez administrację samorządową a odczuwaną przez nich jakością życia.

\section{Metodyka badania}

Badanie z wykorzystaniem kwestionariusza ankiety bezpośredniej zrealizowano w okresie: październik 2014 r. - czerwiec 2015 r. na losowo dobranej próbie (dobór warstwowy) dorosłych 1086 mieszkańców w 7 wylosowanych miastach ${ }^{3}$. Przedmiotem przeprowadzonego badania była jakość życia w wybranych miastach akademickich. Badania przeprowadzono w następujących miastach: Warszawa, Kraków, Poznań, Wrocław, Katowice, Częstochowa i Szczecin. Zakładaną strukturę próby ustalono na podstawie danych statystycznych zamieszczonych w Banku Danych Lokalnych na stronie www.stat.gov.pl. Ze względu na rozbieżności występujące pomiędzy wytypowaną strukturą próby a strukturą próby, dokonano jej ważenia próby ze względu na płeć, wiek i wykształcenie. $Z$ uwagi na ograniczenia co do objętości artykułu, zaprezentowano w nim jedynie wybrane wyniki badań.

Pytanie dotyczące jakości życia zawierało prośbę o ocenę 23 aspektów odnoszących się do warunków życia w mieście. $Z$ kolei podstawą oceny poziomu satysfakcji klienta/mieszkańca z usług JST były odpowiedzi na trzy pytania zawarte w kwestionariuszu ankietowym. Pierwsze z nich dotyczyło subiektywnej oceny zadowolenia z usług, drugie - różnicy między otrzymywanymi usługami a oczekiwaniami respondentów względem tych usług, trzecie zaś koncentrowało się na różnicy między dostarczonymi usługami a wyobrażanym ich ideałem.

Do oszacowania rzetelności pomiaru użyto współczynnika $\alpha$-Cronbacha, który jest jednym z najczęściej stosowanych w pomiarze homogeniczności skali. Współczynnik ten przyjmuje wartości od 0 do 1 , ale brakuje zgodności w literaturze co do jego wystarczającej wartości. Dla jednych autorów zadowalającymi wartościami są te mające wartość większą od 0,6 [Dyduch 2011; Sagan 1998] lub 0,7 [Churchill Jr

${ }^{3}$ Badania te przeprowadzono w ramach badań statutowych Katedry Marketingu. W skład zespołu badawczego poza autorem wchodziły także dr hab. prof. US Augustyna Burlita, dr hab. prof. US Jolanta Witek oraz prof. dr hab. Anna Dąbrowska. 
1979; Peter 1979], inni wyróżniają trzy poziomy badań, dla których sugerują wartość minimalną współczynnika (badania wstępne - wartość współczynnika co najmniej 0,7; badania podstawowe - wartość 0,8 ; badania stosowane - wartość $0,90-0,95$ ) [Nunnally 1978]. Uzyskane wyniki wskazują na wysoką rzetelność wykorzystanych skal. Współczynnik $\alpha$-Cronbacha dla skali oceniającej zadowolenie z usług wyniósł 0,84, zaś dla skali mierzącej satysfakcję z warunków życia w mieście 0,89 .

\section{Ocena jakości życia w badanych miastach}

Wśród badanych mieszkańców siedmiu miast poziom deklarowanego przywiązania do miejsca zamieszkania można uznać za mało zróżnicowany. Zdecydowana większość ankietowanych (69\%) ma pozytywny stosunek do swojego miasta i jest zadowolona z zamieszkiwania w nim. Przeciwnego zdania jest tylko $14 \%$ respondentów, a 16\% nie potrafiło zająć w tej kwestii jednoznacznego stanowiska.

Potwierdzeniem poziomu zadowolenia z miasta zamieszkania jest deklaracja poczucia przynależności do miasta. Takie poczucie ma $66 \%$ badanych. Przeciwnego zdania jest tylko $14 \%$, a $19 \%$ nie miało jednoznacznej opinii w tym względzie.

Zadowolenie z miejsca zamieszkania oraz deklaracja poczucia przynależności nie znajdują natomiast odzwierciedlenia w odpowiedziach dotyczących przekonania o osobistym wpływie respondentów na to, co się dzieje w mieście (rysunek 1). Blisko połowa badanych nie ma poczucia bezpośredniego wpływu na to, co się dzieje w miejscu ich zamieszkania.

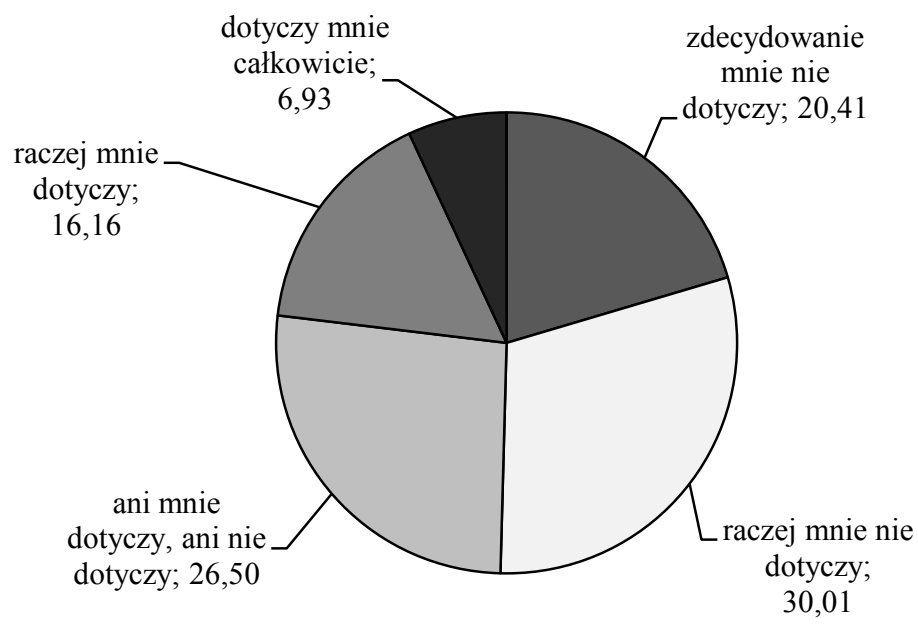

Rys. 1. Przekonanie badanych o posiadaniu osobistego wpływy na to, co się dzieje w mieście (\% odpowiedzi)

Źródło: opracowane własne na podstawie wyników badania ankietowego. 
Najwyższym poziomem relacji pomiędzy mieszkańcami a miastem jest poczucie dumy z miejsca zamieszkania. Deklaruje ją 57\% respondentów, a $28 \%$ nie ma na ten temat zdania. Na poczucie braku dumy w badanych miastach wskazało $14 \%$ osób. Zbliżony odsetek badanych (16\%) nie jest w stanie jednoznacznie określić, czy swoją przyszłość wiąże $\mathrm{z}$ danym miastem. Jednak zdecydowana większość (64\%) chce związać swoją przyszłość z danym miastem. Przeciwnego zdania jest $19 \%$ respondentów.

Badani mieszkańcy w ramach pytań dotyczących jakości życia zostali poproszeni o ocenę satysfakcji z warunków życia $w$ danym mieście. Uzyskane średnie oceny $\mathrm{z}$ analizowanych 23 aspektów nie przekraczają wartości $4 \mathrm{w}$ skali pięciostopniowej ${ }^{4}$. Najwyższy poziom zadowolenia można zaobserwować w przypadku oceny sieci handlowo-usługowej. Średnia ocena wynosi bowiem 3,99, zaś współczynnik zmien-

Tabela 1. Średnie oceny warunków życia w badanych miastach

\begin{tabular}{|l|c|c|}
\hline \multicolumn{1}{|c|}{ Oceniany aspekt } & $\begin{array}{c}\text { Średnia } \\
\text { ocena }\end{array}$ & $\begin{array}{c}\text { Współczynnik } \\
\text { zmienności } \\
\text { (w \%) }\end{array}$ \\
\hline Sieć handlowo-usługowa & 3,99 & 22,16 \\
\hline Szkoły wyższe & 3,68 & 29,42 \\
\hline Komunikacja miejska & 3,63 & 25,85 \\
\hline Infrastruktura kulturalna & 3,54 & 28,80 \\
\hline Tereny zielone (parki, skwery itp.) & 3,49 & 30,84 \\
\hline Szkoły podstawowe/gimnazjalne/licea i technika & 3,48 & 26,83 \\
\hline Relacje z sąsiadami & 3,46 & 32,08 \\
\hline Infrastruktura sportowo-rekreacyjna & 3,42 & 31,22 \\
\hline Sieć dróg & 3,28 & 28,51 \\
\hline Powiązania komunikacyjne miasta w układzie krajowym i międzynarodowym & 3,21 & 35,13 \\
\hline Estetyka przestrzeni miejskiej & 3,19 & 32,46 \\
\hline Ścieżki rowerowe & 3,18 & 34,00 \\
\hline Czystość miasta & 3,11 & 33,05 \\
\hline Poziom hałasu w mieście & 3,08 & 32,67 \\
\hline Bezpieczeństwo mieszkańców & 3,08 & 27,75 \\
\hline Żłobki/przedszkola & 3,02 & 34,48 \\
\hline Życie nocne miasta & 2,98 & 40,39 \\
\hline Dostęp do bezprzewodowego internetu w przestrzeni miejskiej & 2,95 & 39,33 \\
\hline Służba zdrowia & 2,85 & 39,23 \\
\hline Miejsca pracy & 2,80 & 40,16 \\
\hline Stan dróg & 2,63 & 36,89 \\
\hline Łatwość przemieszczania się po mieście samochodem & 2,59 & 39,62 \\
\hline Parkingi, miejsca postojowe & 2,40 & 43,14 \\
\hline
\end{tabular}

Źródło: opracowane własne na podstawie wyników badania ankietowego.

${ }^{4}$ Gdzie 1 oznacza ocenę najniższą, zaś 5 najwyższą. 
ności 22\% nie wskazuje na istotne zróżnicowanie opinii badanych w tym zakresie 5 . W dalszej kolejności relatywnie wysoko oceniono:

- szkoły wyższe (średnia ocena: 3,68; współczynnik zmienności: 29\%),

- komunikację miejską (odpowiednio: 3,63;26\%),

- infrastrukturę kulturalną, tj. liczbę i lokalizację placówek i instytucji kultury, imprezy kulturalne $(3,54 ; 29 \%)$,

- tereny zielone, np. parki, skwery $(3,49 ; 31 \%)$,

Szczegółowe zestawienie średnich ocen satysfakcji z warunków życia w badanych miastach prezentuje tabela 1 .

Najniższy poziom zadowolenia dotyczy typowych miejskich problemów, tj. parkingów, łatwości przemieszczania się po mieście samochodem, stanu dróg, jak również miejsc pracy czy służby zdrowia.

Na poziomie porównywalnym do ocen satysfakcji z warunków życia w mieście kształtuje się deklarowana ocena ogólnego zadowolenia z życia. Średnia ocena wynosi 3,77 w skali pięciostopniowej, zaś najczęściej wskazywaną odpowiedzią było zadowolony.

\section{Satysfakcja klienta $z$ usług świadczonych przez wladze badanych miast}

Satysfakcja badanych mieszkańców z całościowych osiągnięć władz miasta w odniesieniu do rozwoju społeczno-gospodarczego swojego miasta nie jest wysoka. Średnia ocena wynosi 3,02 w skali pięciostopniowej ${ }^{6}$, zaś współczynnik zmienności wynosi 33\%. Rozkład odpowiedzi wskazuje na przewagę osób odczuwających satysfakcję nad osobami odczuwającymi niezadowolenie. Jedna czwarta badanych to osoby deklarujące niezadowolenie lub całkowite niezadowolenie, zaś przeciwnego zdania jest ponad jedna trzecia badanych (32\%). Istnieje również duża grupa deklarująca niewielki poziom satysfakcji z całościowych osiągnięć władz danego miasta $(42 \%)$.

Na podobnym poziomie kształtuje się satysfakcja ankietowanych z usług dostarczanych przez władze miasta zamieszkania. Poziom satysfakcji mieszkańców z usług administracyjnych i społecznych nie przekracza bowiem 3 punktów w skali pięciostopniowej ${ }^{7}$. Najniższy poziom satysfakcji można zauważyć w przypadku usług społecznych. Średni poziom satysfakcji wynosi 2,82 pkt przy współczynniku zmienności 37\%. Znaczna część badanych (34\%) jest całkowicie niezadowolona lub niezadowolona $\mathrm{z}$ tych usług. Kolejna grupa to osoby zadowolone w niewielkim stop-

\footnotetext{
${ }^{5}$ Przyjmuje się następującą interpretację wartości współczynników zmienności: $\mathrm{V}<20 \%$ - mała zmienność; $20 \%<\mathrm{V}<40 \%$ - przeciętna zmienność; $40 \%<\mathrm{V}<100 \%$ - duża zmienność; $100 \%<$ $\mathrm{V}<150 \%$ - bardzo duża zmienność; $\mathrm{V}>150 \%$ - skrajnie duża zmienność.

${ }^{6}$ Gdzie 1oznacza całkowite niezadowolenie, zaś 5 - całkowite zadowolenie.

7 Wartość 3 oznacza mało zadowolonych.
} 
niu (39\%). Znacznie mniejszy odsetek badanych deklaruje, że jest usatysfakcjonowany jakością usług społecznych w miejscu zamieszkania (23\%). Tylko niespełna $4 \%$ badanych stwierdza, że jest z nich całkowicie zadowolona.

Nieznacznie wyższy jest poziom satysfakcji mieszkańców z usług administracyjnych (średnia wartość 2,91 ; współczynnik zmienności 36\%). Najwyższy poziom satysfakcji można zaś zaobserwować w przypadku usług technicznych (odpowiednio: 3,$11 ; 32 \%)$. Porównując rozkłady odpowiedzi z wcześniej opisanymi ocenami usługi społecznych, można zauważyć niższy poziom niezadowolenia i wyższy odsetek osób mało zadowolonych (rysunek 2).

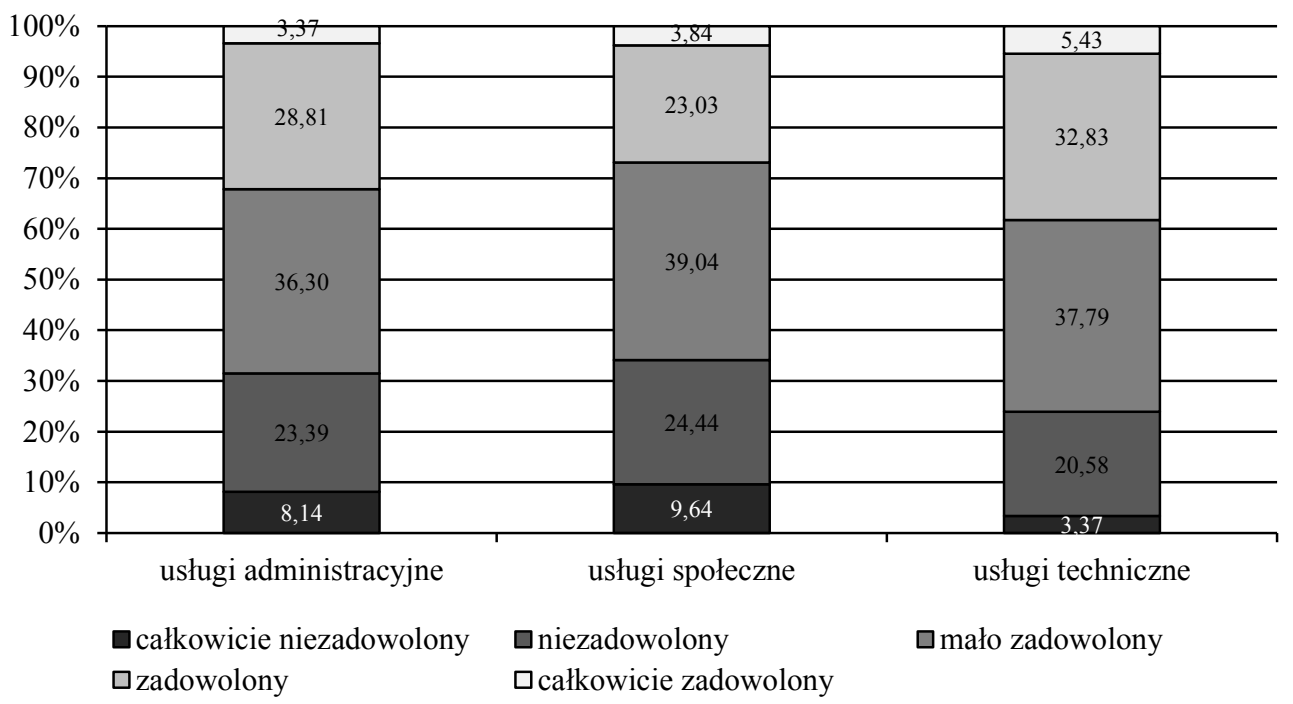

Rys. 2. Rozkład zadowolenia mieszkańców miasta z usług administracyjnych technicznych i społecznych dostarczanych przez władze miasta (\% odpowiedzi)

Źródło: opracowane własne na podstawie badania ankietowego.

Respondenci zostali także poproszeni o określenie odczuwanej przez nich różnicy między otrzymywanymi usługami a swoimi oczekiwaniami względem tych usług, jak i różnicy między dostarczonymi usługami a wyobrażanym ich ideałem. W pierwszym przypadku średnia wartość wynosi 2,64 , co oznacza, że usługi dostarczane przez władze miast spełniają oczekiwania mieszkańców jedynie w niewielkim stopniu. $8 \%$ badanych uważa, że dostarczone usługi nie spełniają ich oczekiwań w ogóle. Blisko połowa badanych (48\%) deklaruje, że ich oczekiwania są raczej spełnione, a jedynie $10 \%$ uznało, że ich oczekiwania zostały spełnione całkowicie. Zbliżony obraz wyłania się z odpowiedzi na pytanie o różnicę między dostarczonymi usługami a wyobrażonym przez respondentów ideałem, co przedstawia rysunek 3 . W tym przypadku średnia wartość wynosi 2,42 , co zgodnie z opisem werbalnym skali pomiaru należy uznać raczej za ocenę daleką od ideału. 


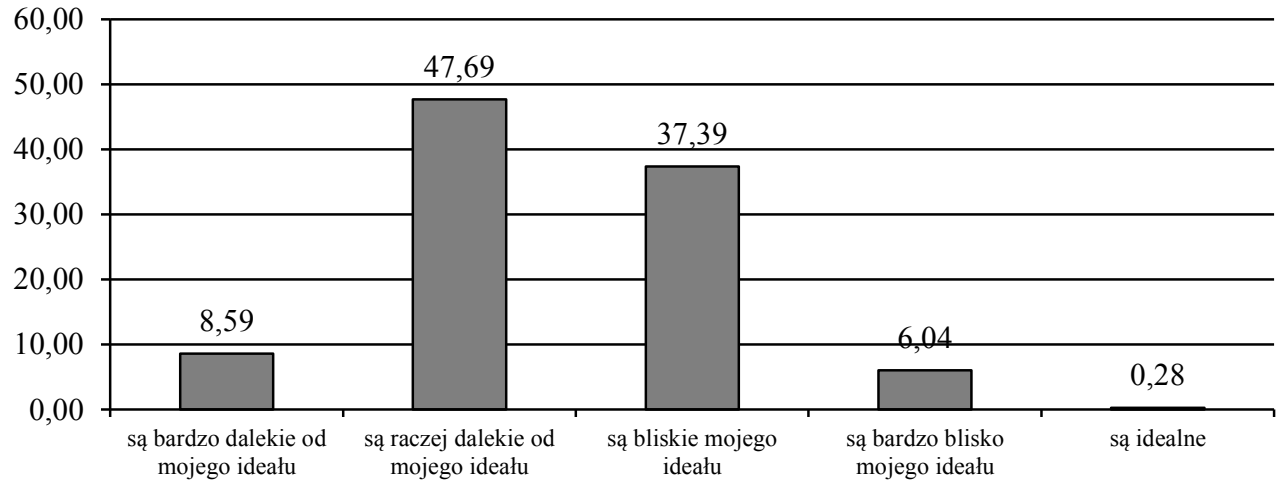

Rys. 3. Opinie badanych na temat różnicy między dostarczonymi usługami a wyobrażonym przez respondentów ideałem (\% odpowiedzi)

Źródło: opracowane własne na podstawie badania ankietowego.

\section{Relacje między ocenami jakości życia i jakości usług świadczonych przez miasta}

Aby oszacować różnice między grupami respondentów ze względu na ocenę jakości usług oraz postrzeganą jakość swojego życia, przeprowadzono analizę skupień. Jako podstawę analizy przyjęto odpowiedzi respondentów na pytania dotyczące satysfakcji z warunków życia w mieście, ich ogólnego zadowolenia z życia oraz oceny satysfakcji z usług dostarczanych przez władze miasta ${ }^{8}$. W celu określenia liczby wyodrębnionych skupisk zastosowano metodę Warda (ostatecznie wyodrębniono 3 skupienia), a następnie w celu ostatecznego przyporządkowania jednostek do skupisk wykorzystano metodę k-średnich.

Dokonując charakterystyk poszczególnych grup na podstawie udzielonych odpowiedzi, można zauważyć, że osoby tworzące drugie skupienie $\left(n_{2}=359\right.$ jednostek) mają najlepszą ze wszystkich grup opinię na temat jakości świadczonych usług. Wszystkie oceny stopnia zadowolenia z usług są większe lub zbliżone do wartości 3,5 w skali pięciostopniowej. Najwyżej oceniane są usługi techniczne $(3,81 \mathrm{w}$ skali pięciostopniowej), zaś najniżej usługi społeczne $(3,48)$. Są to również osoby zadowolone ze swojego życia (średnia ocena 4,0). Respondenci tworzący dane skupienie najwyżej oceniają następujące warunki życia w mieście: sieć handlowo-usługową (średnia ocena: 4,53), szkoły wyższe $(4,48)$, infrastrukturę kulturalną $(4,45)$ oraz komunikację miejską $(4,31)$. Najniższe oceny dotyczą warunków poruszania się po mieście samochodem: łatwości przemieszczania się $(3,02)$, parkingów i miejsc po-

${ }^{8}$ Przed wykonaniem analizy skupień przeprowadzono analizę korelacji wybranych zmiennych. Wyniki wskazują na występowanie słabych związków między zmiennymi. 


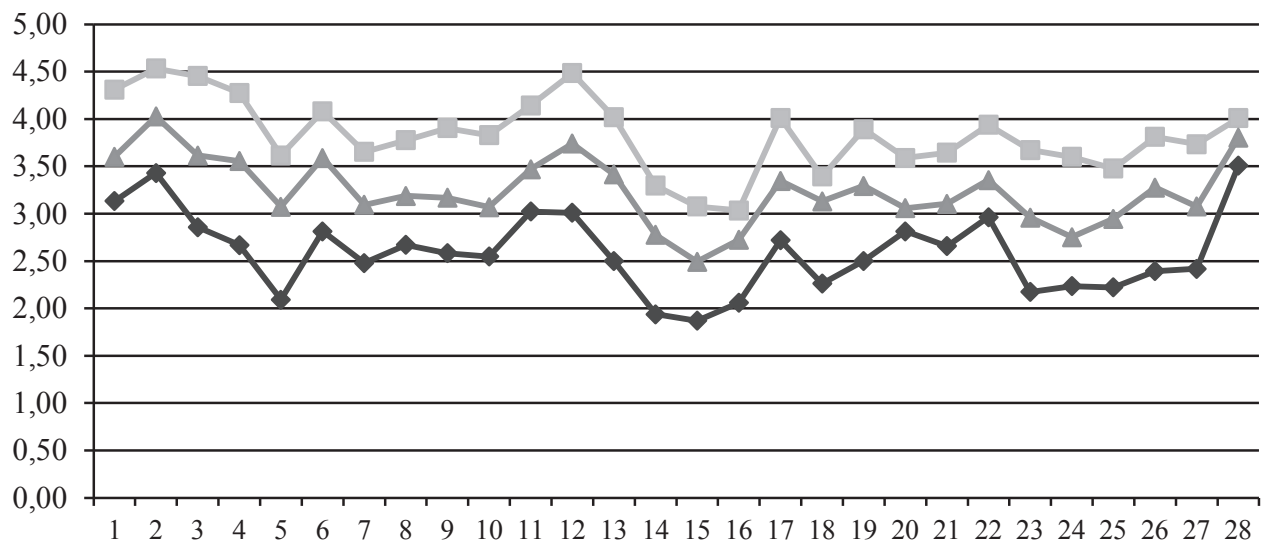

$\multimap$ skupienie $1 \multimap$ skupienie $2 \multimap$ skupienie 3

1- komunikacja miejska; 2 - sieć handlowo-usługowa; 3 - infrastruktura kulturalna; 4 - infrastruktura sportowo-rekreacyjna; 5 - służba zdrowia; 6 - tereny zielone; 7 - czystość miasta; 8 - estetyka przestrzeni miejskiej; 9 - ścieżki rowerowe; 10 - żłobki/przedszkola; 11 - szkoły podstawowe/ gimnazjalne/licea i technika; 12 - szkoły wyższe; 13 - sieć dróg; 14 - stan dróg; 15 - parkingi, miejsca postojowe; 16 - łatwość przemieszczania się po mieście samochodem; 17 - powiązania komunikacyjne miasta w układzie krajowym i międzynarodowym; 18 - dostęp do bezprzewodowego Internetu w przestrzeni miejskiej; 19 - życie nocne miasta; 20 - poziom hałasu w mieście; 21 - bezpieczeństwo mieszkańców; 22 - relacje z sąsiadami; 23 - miejsca pracy; 24 - satysfakcja z usług administracyjnych; 25 - satysfakcja z usług społecznych; 26 - satysfakcja z usług technicznych; 27 - satysfakcja z całościowych osiągnięć władz miasta w odniesieniu do rozwoju społeczno-gospodarczego miasta; 28 - zadowolenie z życia - ogólnie.

Rys. 4. Wartości średnie dla każdego skupienia

Źródło: opracowanie własne na podstawie badania ankietowego.

stojowych $(3,08)$ oraz stanu dróg $(3,30)$. Szczegóły dotyczące ocenianych aspektów prezentuje rysunek 4 .

Przeciwieństwem skupienia drugiego pod względem poziomu ocen są respondenci tworzący skupienie pierwsze $\left(n_{1}=307\right.$ jednostek). W tej grupie poziom zadowolenia z jakości świadczonych usług jest mniejszy od 2,5 w skali 5-stopniowej. Poziom zadowolenia z życia jest niższy i wynosi 3,5. Niskie są również oceny dotyczące zadowolenia z warunków życia w mieście. Najwyżej oceniono sieć handlowo-usługową $(3,43)$, zaś najniżej dostępność parkingów i miejsc postojowych $(1,87)$. Istnieje również grupa, którą można określić mianem „środkowej”, gdzie uzyskane wyniki są zbliżone do średnich wyników uzyskanych dla całej badanej populacji (trzecie skupienie $n_{3}=531$ ). 


\section{Zakończenie}

Zestawienie wyników dla dwóch skrajnych grup pozwala na wyciągnięcie wniosku, iż wyższym ocenom zadowolenia $\mathrm{z}$ warunków życia $\mathrm{w}$ mieście towarzyszą wyższe oceny zadowolenia z całokształtu własnego życia oraz jakości usług dostarczanych przez władze miasta. Uzyskane wyniki pozwalają na pozytywną weryfikację hipotezy o związku między jakością życia a satysfakcją z usług świadczonych przez jednostki samorządu terytorialnego. W celu ostatecznej weryfikacji należałoby przeprowadzić badania, na podstawie których możliwe byłoby wyznaczenie indeksów jakości życia i satysfakcji z usług JST, co będzie przedmiotem zainteresowania autora $\mathrm{w}$ kolejnych realizowanych projektach badawczych.

\section{Literatura}

Andreaseen T.W., 1994, Satisfaction, Loyalty and Reputation as Indicators of Customer Orientation in the Public Sector, International Journal of Public Sector Management, vol. 7, no. 2, s. 16-34.

Borys T., 2008, Propozycja siedmiu typologii jakości życia, Prace Naukowe Akademii Ekonomicznej we Wrocławiu, nr 22, s. 125-134.

Bugdol M., 2011, Zarządzanie jakością w urzędach administracji publicznej. Teoria i praktyka, Difin, Warszawa.

Campbell A., 1976, Subjective measures of well-being, American Psychologist, vol. 31, no. 2, s. 117 $-124$.

Campbell A., Converse P.E., Rogers W.L., 1976, The Quality of American Life: Perception, Evaluation, and Satisfaction, Rasel Sage Foundation, New York.

Churchill Jr G.A., 1979, A Paradigm for developing better measures of marketing constructs, Journal of Marketing Research, no. 1.

Dagger T.S., Sweeney J.C., 2006, The effect of service evaluations on behavioral intentions and quality of life, Journal of Service Research, vol. 9, no.1, s. 3-18.

Dalkey N.C., Rourke D.L., 1972, The Delphi Procedure and Rating Quality of Life Factors, University California, Los Angeles.

Demski T., 2003, Lojalność, satysfakcja - ich znaczenie i pomiar, http://www.statsoft.pl/portals/0/Downloads/znacz.pdf (10.01.2016).

Dyduch W., 2011, Ilościowe badanie i operacjonalizacja zjawisk w naukach o zarzadzaniu, [w:] Czakon W. (red.), Podstawy metodologii badań w naukach o zarządzaniu, Wolters Kluwer Polska, Warszawa.

Kowalska M., Marcinkowska U., Jośko J., 2010, Satysfakcja z pracy zawodowej a jakość życia kobiet $w$ wieku 45-60 lat w województwie śląskim, Medycyna Pracy, vol. 61, no. 3, s. 277-285.

Modzelewski P., 2009, System zarządzania jakościa a skuteczność i efektywność administracji samorządowej, CeDeWu, Warszawa.

Nunnally J.C., 1978, Psychometric Theory, McGraw-Hill, New York.

Peter J.P., 1979, Reliability: A review of psychometric basic and recent marketing practices, Journal of Marketing Research, no. 1.

Przygodzka R., 2010, Ustugi publiczne a jakość życia w regionach peryferyjnych, [w:] Noworól A. (red.), Jakość życia a procesy zarządzania rozwojem i funkcjonowaniem organizacji publicznych, (tom II), Instytut Sprawa Publicznych Uniwersytetu Jagiellońskiego w Krakowie, Kraków. 
Sagan A.,1998, Badania marketingowe. Podstawowe kierunku, Wyd. AE w Krakowie, Kraków. Strąk T., 2012, Modele dokonań jednostek sektora finansów publicznych, Difin, Warszawa. Szymańska D., 2008, Urbanizacja na świecie, Wydawnictwo Naukowe PWN, Warszawa.

Ustawa o samorządzie gminnym, tekst jednolity, Dz.U. z 2001, Nr 142, poz. 1591 z późniejszymi zmianami.

Wołowska A., 2013, Satysfakcja z pracy i jej wyznaczniki a poczucie jakości życia urzędników, Rocznik Andragogiczny, vol. 20, s. 119-132.

Woodruff R.B., Gardial S.F., 1996, Know Your Customer. New Approaches to Understanding Customer Value and Satisfaction, Blackwell Publisher Inc., Cambridge. 